\title{
Synthesis and Crystal Structure of Zinc Iodide in the Sodalite Cavities of Zeolite A (LTA)
}

\author{
Seok Han Kim, ${ }^{a}$ Man Park, ${ }^{\text {b* }}$ Young Ja Son, ${ }^{c}$ Hyung Joo Lee, ${ }^{d}$ Gyo Cheol Jeong, Myung Nam Bae, ${ }^{f}$ and Woo Taik Lim ${ }^{c *}$ \\ aepartment of Applied Chemistry, Kungpook National Lniversity, Daegu 702-701, Korea \\ 'Department of Agricultural Chemistry, Kunngpook National Lniversity, Daegu 702-701, Korea

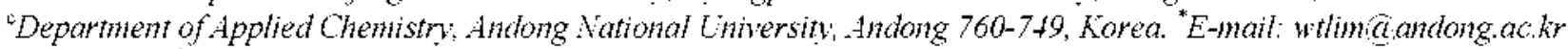 \\ department of Electronics Engineering, Andong Kational Lniversitw, Andong 760-749, Korea \\ 'Department of Earth and Enwironmental Sciences, Andong Kational Lniversity, Andong 760-749, Korea \\ ${ }^{\mathrm{f}}$ Department of Chemistry, Pusan National Lniversitv, Pusan 609-735, Korea \\ Recerved November 23, 2006
}

\begin{abstract}
The cry'stal structure of $\mathrm{ZnI}_{2}$ molecule șinthesized in zeolite $\mathrm{A}$ (LTA) has been studied by single-cry'stal X-ray diffraction techniques. A single crystal of $\mid \mathrm{Zn}_{6}\left[\left[\mathrm{Si}_{1} \mathrm{Al}_{2} \mathrm{~A}_{2} \mathrm{O}_{48}\right]-\mathbf{L T A}\right.$. synthesized by the dy namic ion-exchange of $\left|\mathrm{Na}_{1}\right|\left[\mathrm{Si}_{1 \beth} \mathrm{Al}_{12} \mathrm{O}_{48}\right]-\mathbf{L T A}$ with aqueous $0.05 \mathrm{M} \mathrm{Zn}\left(\mathrm{NO}_{3}\right)_{2}$ and washed with deionized water. was placed in a stream of flowing $0.05 \mathrm{M} \mathrm{KI}$ in $\mathrm{CH}_{3} \mathrm{OH}$ at $294 \mathrm{~K}$ for four days. The resulting crystal structure of the product $\left(\left|\mathrm{K}_{6} \mathrm{Zn}_{3}\left(\mathrm{KI}_{3}\right)_{3}\left(\mathrm{ZnI}_{2}\right)_{15}\right|\left[\mathrm{Si}_{1} \mathrm{Al}_{1} \mathrm{O}_{28} \mathrm{O}_{48}\right]-\mathrm{LTA} a=12.1690(10) \AA\right.$ ) was determined at $294 \mathrm{~K}$ by single-crystal X-ray diffraction in the space group $P m \overline{3} m$. It was refined with all measured reflections to the final error index $R_{1}=$ 0.078 for $43 \mathrm{l}$ reflections which $F_{0}>4 \sigma\left(F_{0}\right)$. At four crystallographically distinct positions. $3.5 \mathrm{Zn}^{2+}$ and nine $\mathrm{K}^{+}$ions per unit cell are found: three $\mathrm{Zn}^{2+}$ and five $\mathrm{K}^{+}$ions lie on the 3-fold axes opposite 6 -rings in the large cavity two $\mathrm{K}^{+}$ions are off the plane of the 8-rings. two $\mathrm{K}^{+}$ions are recessed deeply off the plane of the 8-rings. and the remaining a half $\mathrm{Zn}^{-2}$ ion lie on the 3-fold axes opposite 6-rings in the sodalite cavity. A half $\mathrm{Zn}^{2-}$ ion and an $\mathrm{I}^{-}$ion per unit cell are found in the sodalite units. indicating the formation of a $\mathrm{ZnI}_{2}$ molecule in $50 \%$ of the sodalite cavities. Each $\mathrm{ZnI}_{2}(\mathrm{Zn}-\mathrm{I}=3.35(5) \AA)$ is held in place by the coordination of its one $\mathrm{Zn}^{2-}$ ion to the zeolite framework oxygens and by the coordination of its two $\mathrm{I}^{-}$ions to $\mathrm{K}^{+}$ions through 6 -rings $(\mathrm{I}-\mathrm{K}=3.33(8)$ A). Three additional $\mathrm{I}^{-}$ions per unit cell are found opposite a 4-ring in the large cavity and form a $\mathrm{K}_{3} \mathrm{I}^{2-}$ and two $\mathrm{K}_{2} \mathrm{ZnI}^{\mathrm{j}-}$ ionic clusters. respectively.
\end{abstract}

Key Words : Zeolite A, Zinc iodide, Single-crystal X-ray diffraction, Crystal structure

\section{Introduction}

Metal compound catalysts in solution or supported on solids. such as silica gel and zeolites. are used extensively. ${ }^{1-6}$ Zeolites are one of the best supports for catalysts in the petro- and organo-chemical industries. Zeolites ion-exchanged by transition metal ions are also useful catalysts. ${ }^{1.7}$ The catalytic properties of zeolites supported transition metal compounds have been studied intensively. " Various metal compounds and zeolites have been chosen to develop and control advanced catalytic reactions. ${ }^{1}$ These catalytic reactions can be more easily controlled by using zeolites as support because the unique-sized metal compounds which are catalytically active materials. can be synthesized and stabilized in regular three-dimensionally arrayed cavities of zeolites. Additionally. the reactants and products can also be controlled due to the shape-selectivities of zeolites. ${ }^{\text {\& }}$

Zinc halides. $\mathrm{ZnX}$ ( $(\mathrm{X}=\mathrm{Cl}$. Br. I), are used as catalysts in various organic reactions. For cross-coupling reactions of carbony lmethy' units using $\alpha$-chloroketones and tin enolates. zinc halides are used excellent catalysts. ${ }^{9}$ One function of the $\mathrm{ZnX}_{3}$ in the reactions is to serve as a Lewis acid promoting the precondensation step. Polymer-supported zinc halides. $(\mathrm{PVP}) \mathrm{ZnX}_{2}(\mathrm{PVP}=$ poly (4-viny lpyridine) $\mathrm{X}=\mathrm{Cl}$. $\mathrm{Br}$. I). have also been reported as heterogeneous catalysts with high selectivity and activity for the coupling reactions of carbon dioxide and epoxides. ${ }^{2} \mathrm{ZnCl}_{2}, \mathrm{ZnI}_{2}$, and $\mathrm{TiCl}_{4}$ supported on silica gel are more efficient catalysts in various organic reactions. ${ }^{3-5}$ such as the Friedel-Crafts alkylation of benzene with alkyl chlorides ${ }^{3}$ and Diels-Alder reactions with different dienophiles ${ }^{4.5}$ even though $\mathrm{ZnX}_{2}$ and $\mathrm{TiCl}_{4}$ are already good catalysts for these reactions. ${ }^{3}$ The applicability of these materials in Diels-Alder reactions of furan is improved by supporting it on silica gel. ${ }^{3}$ Additionally. silica gel-supported $\mathrm{ZnX}$ catalysts also provide an efficient synthesis of aryl-substituted halo olefins from aromatic ketones and acetyl halides with the some advantages of operational simplicity. mild conditions. high yield. and stereoselectivity.

Group II $b$ iodides. $\mathrm{ZnI}_{\lrcorner} . \mathrm{CdI}_{2}$. and $\mathrm{HgI}_{3}$, have been studied for their optical properties. ${ }^{10.11}$ Specifically. $\mathrm{HgI}_{2}$ has been studied because of its optical properties and its utility as radiation detector and $\mathrm{CdI}_{2}$ has also been extensively researched due to its polytypism. ${ }^{10111}$ In recent decades. the optical and structural properties of $\mathrm{ZnI}_{2}$ film s have also been studied using optical-absorption measurement. ${ }^{[0.11}$ The optical band gap of $\mathrm{ZnI}_{2}$ films is the direct-type and shows thickness dependence related packing density and size distribution of crỵstallite grains. ${ }^{10.13}$ A large decrease in band gap has been attributed to the large $c / a$ and this result indicates the optical 
properties of group II $b$ iodides are changed by their crystal structures. ${ }^{[(i), 1]}$

In this work, we have attempted to sy'nthesize $\mathrm{ZnI}$ - clusters in a single crystal of zeolite $A$ and to determine its structure. This was done because the $\mathrm{ZnI}$ : clusters in the unique-sized and regular three-dimensionally orientated cavities of zeolites are predicted to be advanced catalytic and optical

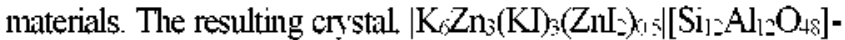
LTA including $\mathrm{ZnI}$ : molecules. was prepared through a reaction of $\mathrm{KI}$ in $\mathrm{CH}_{3} \mathrm{OH}$ solution with the fully $\mathrm{Zn}^{3+}$. exchanged zeolite $\mathrm{A}\left(\mid \mathrm{Zn} \mathrm{n}_{6}\left[\mathrm{Si}_{1} \mathrm{Al}_{l_{2}} \mathrm{O}_{48}\right]-\mathbf{L T A}\right)$. The crystal structure of the resulting product was determined to verify that nanoclusters had formed. to learn their positions. size. and geometry and to observe their interactions with zeolite framework. The method used closely parallel those reported earlier for $\left.\mid \mathrm{K}_{9}\left(\mathrm{~K}_{4} \mathrm{D}\right)\left(\mathrm{Ag}_{4} \mathrm{I}_{4}\right) \hat{c}_{1}\right]\left[\mathrm{Si}_{1} \mathrm{Al}_{l_{2}} \mathrm{O}_{4 \beta}\right]-\mathrm{LTA}{ }^{12}$ $\left|\mathrm{K}_{9}\left(\mathrm{~K}_{4} \mathrm{Br}\right)^{-} \quad\left(\mathrm{Ag}_{4} \mathrm{Br}_{4}\right)_{17}\right|\left[\mathrm{Si}_{1} \mathrm{Al}_{1_{2}} \mathrm{O}_{48}\right]-$ LTA ${ }^{13}$ and $\left|\mathrm{K}_{(}\left(\mathrm{Pb}_{4} \mathrm{I}_{2}\right)\left(\mathrm{PbI}_{2}\right)_{66}\left(\mathrm{H}_{2} \mathrm{O}\right)_{2}\right|-\left[\mathrm{Si}_{12} \mathrm{Al}_{12} \mathrm{O}_{48}\right] \cdot \mathbf{L T A}{ }^{14}$

\section{Experimental Section}

Large colorless single crystals of zeolite $4 \mathrm{~A}\left(\left|\mathrm{Na}_{12}\left(\mathrm{H}_{2} \mathrm{O}\right)_{27}\right|-\right.$ $\left[\mathrm{Si}_{1} \mathrm{Al}_{12} \mathrm{O}_{4 \xi}\right]$-LTA. $\mathrm{Na}_{12}-\mathrm{A}$. or $\mathrm{Na}-\mathrm{A}$ ) were synthesized by Kokotailo and Charnell. ${ }^{15}$ These crystals were from the same batch as all previous zeolite A single crystals reported from K. Seff's and N. H. Heo's laboratories. ${ }^{13-14}$ A colorless single crystal of hydrated $\mathrm{Na}-\mathrm{A}$ a cube about $80 \mu \mathrm{m}$ on an edge. was lodged in a fine Pyrex capillary. Crystals of hy'drated $\left|\mathrm{Zn}_{5}\right|\left[\mathrm{Si}_{1_{2}} \mathrm{Al}_{l_{2}} \mathrm{O}_{48}\right]-\mathrm{LTA}$ were prepared using the dy'namic (flow) ion-exchange of $\left|\mathrm{Na}_{12}\left(\mathrm{H}_{2} \mathrm{O}\right)_{27}\right|\left[\mathrm{Si}_{1_{2}} \mathrm{Al}_{1_{2}} \mathrm{O}_{48}\right]-$ LTA with aqueous $0.05 \mathrm{M} \mathrm{Zn}\left(\mathrm{NO}_{3}\right)_{2}$ (Aldrich $99.999 \%$ ) at $294 \mathrm{~K}$ for 4 days. ${ }^{16}$ The resulting $\left|\mathrm{Zn}_{6}\right|\left[\mathrm{Si}_{12} \mathrm{Al}_{1}: \mathrm{O}_{48}\right]$-LTA crystal was thoroughly washed with deionized water and then placed in a flowing stream of $0.05 \mathrm{M} \mathrm{KI}$ (Aldrich $99.99 \%$ ) in $\mathrm{CH}_{3} \mathrm{OH}$ (Merck $99.8 \%$ ) at $294 \mathrm{~K}$ for 4 days. No attempt was made to dry the $\mathrm{CH}_{3} \mathrm{OH}$ beforehand. At the end. no attempt was made to remove the solvent from the crystal. neither by evacuation nor heating. The crystal was then isolated in its capillary by sealing both ends with a small torch. After ion-exchange with $\mathrm{Zn}^{-2}$ and a consecutive reaction with $\mathrm{KI}$. the crystal was colorless.

$\mathrm{X}$-ray diffraction data of the single-crystal was collected at 294(1) K on an ADSC Quantum210 detector at Beamline 4A MXW of The Pohang Light Source. The wavelength of the synchrotron X-rays was $0.76999 \AA$. The crystal was rotated through a total of $360^{\circ}$, with a $1.0^{\circ}$ oscillation per frame. We got basic scale file from program the HKL2000 (Otwinowski \& Minor. 1997) program which included the DENZO indexing program with the cubic space group $P 23$. A full-matrix least-squares refinement using SHELEX $97^{17}$ with the cubic space group $P m \overline{3} m$ (no systematic absences) was carried out on this work for reasons discussed previous1y. ${ }^{16.30}$ A summary of the experimental and crystallographic data is presented in Table 1 .

\section{Structure Determination}

Table 1. Summary of Experimental and Crystallographic Data

\begin{tabular}{|c|c|}
\hline Crystal cross-section (mm) & 0.08 \\
\hline Ion exchange for $\mathrm{Zn}^{2+}$ (days, $\mathrm{mL}$ ) & 4,8 \\
\hline Washing with deionized water $(\mathrm{K}$, day) & 294,1 \\
\hline Reaction of $\mathrm{Zn}-\mathrm{A}$ with $\mathrm{KI}$ (days, $\mathrm{mL}$ ) & 4,12 \\
\hline Temperature for data collection $(\mathrm{K})$ & $294(1)$ \\
\hline $\mathrm{X}$-ray source & $\operatorname{PLS}(4 \mathrm{~A} M X W \mathrm{BL})^{\sigma}$ \\
\hline Wavelength $(A)$ & 0.76999 \\
\hline Space group, No. & $\operatorname{Pm} \overline{3} m, 221$ \\
\hline Unit cell constant, $a(\AA)$ & $12.1690(10)$ \\
\hline Maximum $2 \theta$ for data collection (deg) & 61.93 \\
\hline No. of unique reflections measured, $m$ & 483 \\
\hline No. of reflections $\left(F_{0}>4 \sigma\left(F_{0}\right)\right)$ & 431 \\
\hline No. of variables, $s$ & 48 \\
\hline Data/parameter ratio, $n \cdot s$ & 10.1 \\
\hline Weighting parameters : $a / b$ & $0.130 / 8.660$ \\
\hline \multicolumn{2}{|l|}{ Final error indices } \\
\hline$R_{1}^{b}$ & 0.078 \\
\hline$R_{2}{ }^{6}$ & 0.215 \\
\hline Goodness of titt & 1.118 \\
\hline
\end{tabular}

${ }^{B}$ Beamline 4A MXW of Pohang Light Source. ${ }^{b} R_{1}=\Sigma\left|F_{0}-F_{0}\right| \sum F_{0} \cdot R_{1}$ is calculated using only the 431 reflections for thich $F_{0} \% 4 \sigma\left(F_{0}\right) .{ }^{\circ} R_{2}=$ $\left[\operatorname{\sum n}\left(F_{0}^{2}-F_{c}^{2}\right)^{2} \operatorname{Sn}^{2}\left(F_{0}^{2}\right)^{2}\right]^{1: 2} R_{2}$ is calculated using all 483 unique reflections measured. ${ }^{d}$ Goodness-of-fit $\left.=\left(\sum n+F_{0}^{2}-F_{0}^{2}\right)^{2}(m-s)\right)^{1: 2}$.

A full-matrix least-squares refinement using SHELXL $97^{17}$ was done on $F_{0}^{2}$ using all reflections. This began with the atonic parameters of the framework atoms $[(\mathrm{Si}, \mathrm{Al}), \mathrm{O}(1) . \mathrm{O}(2)$. and $\mathrm{O}(3)]$ (see Table 2) in dehydrated $\left|\mathrm{K}_{12}\right|\left[\mathrm{Si}_{12} \mathrm{Al}_{1_{2}} \mathrm{O}_{48}\right]$ LTA. ${ }^{\text {"3 }}$ The initial refinement using isotropic thermal parameters for all positions converged to the error indices (defined in footnotes to Table 1) $R_{1}=0.44$ and $R_{2}=0.78$.

See Table 3 for the steps of structure determination and refinement as new atomic positions were found on successive difference Fourier electron-density functions. The refinement with ten additional peaks from Fourier difference functions and isotropic thermal parameters to refine the framework atoms led to convergence with $R_{1}=0.11$ and $R_{2}=0.32$. These framework atoms and some atoms opposite 6-ring were allowed to refine anisotropically (see Table 2) and the refinement converged to $R_{1}=0.078$ and $R_{2}=0.208$. The final cycles of the refunement were carried out with occupancies fixed at the values given in Tables 2 and 3 . This model converged to the final error indices $R_{1}=0.078$ and $R_{2}=$ 0.215 . In the last cycle of least-squares refinement. all shifts were less than $0.1 \%$ of their corresponding estimated standard deviations. Final structural parameters are presented in Table 2 and selected interatomic distances and angles are given in Table 4.

Fixed weights were used initially: the final weights were assigned using the formula $w=1 /\left[\sigma^{2}\left(F_{0}{ }^{3}\right)+(a P)^{2}+b P\right]$ where $P=\left[\operatorname{Max}\left(F_{0}{ }^{2}, 0\right)+2 F_{0}{ }^{2}\right] / 3$, with $a=0.130$ and $b=$ 8.660 as refined parameters (see Table 1). Atomic scattering

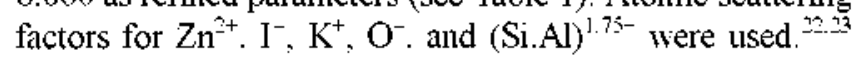
The function describing $(\mathrm{Si}, \mathrm{Al})^{1.75+}$ is the mean of the $\mathrm{Si}^{4+}$. $\mathrm{Si}^{3}, \mathrm{Al}^{2-}$. and $\mathrm{Al}^{\mathrm{i}}$ functions. All scattering factors were 
Table 2. Positional, Themal, and Occupancy Parameters ${ }^{a}$

\begin{tabular}{|c|c|c|c|c|c|c|c|c|c|c|c|c|}
\hline & \multirow{2}{*}{$\begin{array}{l}\text { Wyckoff } \\
\text { position }\end{array}$} & \multirow{2}{*}{$x$} & \multirow{2}{*}{$y$} & \multirow{2}{*}{$z$} & \multirow{2}{*}{$U_{1 \mathrm{I}}$} & \multirow{2}{*}{$U_{32}$} & \multirow{2}{*}{$L_{33}$} & \multirow{2}{*}{$L_{12}$} & \multirow{2}{*}{$U_{13}$} & \multirow{2}{*}{$L_{33}$} & \multicolumn{2}{|c|}{ Occupancy } \\
\hline & & & & & & & & & & & fixed & varied \\
\hline$(\mathrm{Si}, \mathrm{Al})$ & $24(k)$ & 0 & $1830(1)$ & $3686(1)$ & $68(10)$ & $21(10)$ & $a(10)$ & 0 & 0 & $12(5)$ & $24^{c}$ & \\
\hline$O(1)$ & $12(h)$ & 0 & $2126(7)$ & $5000^{7}$ & $1601(121)$ & $409(47)$ & $201(38)$ & 0 & 0 & 0 & 12 & \\
\hline$O(2)$ & $12(i)$ & 0 & $2991(4)$ & $2991(4)$ & $449(39)$ & $232(20)$ & $232(20)$ & 0 & 0 & $56(25)$ & 12 & \\
\hline$O(3)$ & $24(m)$ & $1137(5)$ & $1137(5)$ & $3308(7)$ & $512(25)$ & $512(25)$ & $840(47)$ & $253(29)$ & $-288(28)$ & $-288(28)$ & 24 & \\
\hline $\operatorname{Zn}(1)$ & $8(g)$ & $1623(21)$ & $1623(21)$ & $1623(21)$ & $335(52)$ & $335(52)$ & $335(52)$ & $102(85)$ & $102(85)$ & $102(85)$ & 0.5 & $0.4(2)$ \\
\hline $\operatorname{Zn}(2)$ & $8(\mathrm{~g})$ & $1947(10)$ & $1947(10)$ & $1947(10)$ & $114(28)$ & & & & & & 1 & $1.2(2)$ \\
\hline $\operatorname{Zn}(3)$ & $8(g)$ & $2160(5)$ & $2160(5)$ & $2160(5)$ & $156(14)$ & & & & & & 2 & $2.0(2)$ \\
\hline $\mathrm{K}(1)$ & $8(g)$ & $2544(6)$ & $2544(6)$ & $2544(6)$ & $378(18)$ & $378(18)$ & $378(18)$ & $116(27)$ & $116(27)$ & $116(27)$ & 3 & $3.2(3)$ \\
\hline $\mathrm{K}(2)$ & $8(g)$ & $3022(17)$ & $3022(17)$ & $3022(17)$ & $1131(84)$ & & & & & & 2 & $1.9(2)$ \\
\hline$K(3)$ & $24(m)$ & $326(46)$ & $4589(25)$ & $4589(25)$ & $1462(260)$ & & & & & & 2 & $3.2(5)$ \\
\hline$K(4)$ & $24(l)$ & $1067(54)$ & $4274(51)$ & $5000^{2}$ & $1584(274)$ & & & & & & 2 & $2.3(6)$ \\
\hline $\mathrm{I}(\mathrm{l})$ & $8(g)$ & $964(39)$ & $964(39)$ & $964(39)$ & $4702(528)$ & & & & & & 1 & I. $1(1)$ \\
\hline $\mathrm{I}(2)$ & $24(m)$ & $3115(55)$ & $3115(55)$ & $4442(66)$ & $5832(648)$ & & & & & & 2 & $2.8(4)$ \\
\hline $\mathrm{I}(3)$ & $24(l)$ & $2087(34)$ & $3471(33)$ & $5000^{a}$ & $1347(113)$ & & & & & & 1 & $0.8(2)$ \\
\hline
\end{tabular}

"Positional parameters $\times 10^{4}$ and thennal parameters $\times 10^{4}$ are given. Numbers in parentheses are the estimated standard deviations in the units of the least significant figure given for the corresponding parameter. The anisotropic temperature factor is exp $\left[-2 \pi^{2} a^{-2}\left(U_{1} h^{2}+U_{23 h} h^{2}-U_{33} h^{2}+2 U_{1} / h k+\right.\right.$ $\left.\left.2 U_{1} h l l-2 U_{3} h h\right)\right]$. ${ }^{b}$ Occupancy factors are given as the number of atoms or ions per unit cell. "Occupancy for $(\mathrm{Si})=12$. occupancy for $(\mathrm{Al})=12$. "Exactly 0.5 by symmetry.

Table 3. Steps of Structure Detenmination as Atom Positions Are Found

\begin{tabular}{|c|c|c|c|c|c|c|c|c|c|c|c|c|}
\hline \multirow{2}{*}{$\begin{array}{l}\text { step/ } \\
\text { atom }\end{array}$} & \multicolumn{10}{|c|}{ occupancies per unit cell } & \multicolumn{2}{|c|}{ enor indices ${ }^{f}$} \\
\hline & $\ln (1)$ & $\ln (2)$ & $\ln (3)$ & $\mathrm{K}(1)$ & $\mathrm{K}(2)$ & $K(3)$ & $\mathrm{K}(4)$ & $I(1)$ & $\mathrm{I}(2)$ & I(3) & $R_{1}$ & $R_{2}$ \\
\hline $\mathrm{l}^{a}$ & & & & & & & & & & & 0.435 & 0.780 \\
\hline 2 & & & & $5.1(4)$ & & & & & & & 0.253 & 0.673 \\
\hline 3 & & & $2.3(1)$ & $2.5(3)$ & & & & & & & 0.205 & 0.564 \\
\hline 4 & $0.8(2)$ & & $1.9(2)$ & $2.7(3)$ & & & & & & & 0.172 & 0.534 \\
\hline 5 & $0.6(1)$ & $1.1(2)$ & $2.1(2)$ & $2.7(2)$ & & & & & & & 0.166 & 0.503 \\
\hline 6 & $0.6(1)$ & $1.1(2)$ & $2.1(2)$ & $2.7(2)$ & $2.3(4)$ & & & & & & 0.156 & 0.462 \\
\hline 7 & $0.7(1)$ & $1.1(2)$ & $2.0(2)$ & $2.5(2)$ & $2.3(3)$ & & & $1.4(4)$ & & & 0.147 & 0.455 \\
\hline 8 & $0.5(1)$ & $1.4(2)$ & $1.9(2)$ & $2.3(2)$ & $2.1(3)$ & $1.6(5)$ & & $1.2(3)$ & & & 0.136 & 0.350 \\
\hline 9 & $0.5(1)$ & $1.5(2)$ & $1.8(2)$ & $2.4(2)$ & $2.4(3)$ & $2.7(5)$ & $3.4(6)$ & $1.2(3)$ & & & 0.122 & 0.322 \\
\hline 10 & $0.5(1)$ & $1.5(2)$ & $1.8(2)$ & $2.4(2)$ & $2.4(3)$ & $2.2(5)$ & $2.19)$ & $1.2(3)$ & & $1.0(2)$ & 0.119 & 0.318 \\
\hline 11 & $0.5(1)$ & $1.5(2)$ & $1.9(2)$ & $2.6(2)$ & $2.5(4)$ & $4.3(6)$ & $1.7(9)$ & $1.2(2)$ & $2.5(6)$ & $0.8(2)$ & 0.114 & 0.317 \\
\hline $12^{b}$ & $0.4(1)$ & $1.5(2)$ & $1.8(1)$ & $2.7(1)$ & $1.9(2)$ & $3.2(5)$ & $2.3(6)$ & $1.1(1)$ & $2.8(4)$ & $0.8(4)$ & 0.0786 & 0.210 \\
\hline $13^{c}$ & $0.4(2)$ & $1.2(2)$ & $2.0(2)$ & $3.2(3)$ & $1.9(2)$ & $3.2(5)$ & $2.3(6)$ & $1.1(1)$ & $2.8(4)$ & $0.8(2)$ & 0.0777 & 0.208 \\
\hline $14^{c . d t}$ & 0.5 & 1.0 & 2.0 & 3.0 & 2.0 & 2.0 & 2.0 & 10 & 20 & 1.0 & 0.0783 & 0.215 \\
\hline
\end{tabular}

"The initial step of structure determination as all framework atoms are found. "Framework atoms were allowed to refine anisotropically. 'Framework atoms and some atoms opposite six-ring were allowed to refine anisotropically (see Table 2). ${ }^{d}$ Fixed occupancies are used for all atoms. ${ }^{\text {Defined in }}$ footnotes to Table 2 .

modified to account for anomalous dispersion. $2+, 3 \mathrm{~s}$ Results and Discussion

Zeolite A Framework and Cations. The flex of (distortion to) the framework structure of the zeolite $\mid \mathrm{K}_{6} \mathrm{Zn}_{3}(\mathrm{KI})_{3_{3}-}$ $\left(\mathrm{ZnI}_{2}\right)_{(1 \leq 1} \mid\left[\mathrm{Si}_{1_{2}} \mathrm{Al}_{12} \mathrm{O}_{48}\right]$-LTA is much more like that of hydrat- ed $\left|\mathrm{Zn}_{6}\right|\left[\mathrm{Si}_{1_{\beth}} \mathrm{Al}_{]_{2}} \mathrm{O}_{48}\right]$-LTA and evacuated $\left|\mathrm{K}_{2} \mathrm{Zn}_{5}\right|\left[\mathrm{Si}_{1} \mathrm{Al}_{12} \mathrm{O}_{48}\right]-\mathbf{L T A}$ than that of evacuated $\left|\mathrm{Zn}_{6}\right|\left[\mathrm{Si}_{12} \mathrm{Al}_{12} \mathrm{O}_{48}\right]$-LTA. dehydr- ated $\left|\mathrm{K}_{12}\right|\left[\mathrm{Si}_{12} \mathrm{Al}_{12} \mathrm{O}_{48}\right]-$ LTA. and hydrated $\left|\mathrm{K}_{1 \leq}\right|\left[\mathrm{Si}_{1 \_} \mathrm{Al}_{1_{2}} \mathrm{O}_{48}\right]$-LTA (see Table 5). ${ }^{16,21), 21}$

In each unit cell of the zeolite $\left|\mathrm{K}_{6} \mathrm{Zn}_{3}(\mathrm{KD})_{3}\left(\mathrm{ZnI}_{2}\right)_{(\mathrm{i})}\right|-$ $\left[\mathrm{Si}_{12} \mathrm{Al}_{1_{2}} \mathrm{O}_{48}\right]$-LTA. three and a half $\mathrm{Zn}^{2+}$ and nine $\mathrm{K}^{+}$ions are distributed over four crystallographically distinct positions: on the 3-fold axes opposite 6-ring. a half, one and two $\mathrm{Zn}^{\hat{2}^{-}}$ions are found at $\mathrm{Zn}(1), \mathrm{Zn}(2)$, and $\mathrm{Zn}(3)$. respectively. and three and two $\mathrm{K}^{-}$ions at $\mathrm{K}(1)$ and $\mathrm{K}(2)$, respectively. are also found. Additionally, two $\mathrm{K}^{-}$ions at $\mathrm{K}(3)$ are found on near 8-rings and two $\mathrm{K}^{+}$ions at $\mathrm{K}(4)$ lie on deeply off the plane of the 8-rings in the large cavities. Therefore, the eight 6-rings per unit cell contain three and a half $\mathrm{Zn}^{\hat{2}^{-}}$and five $\mathrm{K}^{+}$ ions; each $\mathrm{Zn}^{2+}$ and $\mathrm{K}^{+}$ion lies on a 3-fold axis and those ions at $\mathrm{Zn}(1)$. $\mathrm{Zn}(2) . \mathrm{Zn}(3) . \mathrm{K}(1)$, and $\mathrm{K}(2)$ extend 0.50 . 0.18 .0 .63 . 1.44, and $2.45 \mathrm{~A}$. respectively, from the (111) planes at $O(3)$ (see Table 6).

The $\mathrm{Zn}^{{ }^{2}-}$ ions at $\mathrm{Zn}(1)$ in the sodalite units, and at $\mathrm{Zn}(2)$ 
Table 4. Selected Interatomic Distances $(\AA)$ and Angles (deg) ${ }^{\sigma}$

\begin{tabular}{llll}
\hline & Distances & & Angles \\
\hline$(\mathrm{Si}, \mathrm{Al})-\mathrm{O}(1)$ & $1.639(3)$ & $\mathrm{O}(1)-(\mathrm{Si}, \mathrm{Al})-\mathrm{O}(2)$ & $108.2(4)$ \\
$(\mathrm{Si}, \mathrm{Al})-\mathrm{O}(2)$ & $1.647(2)$ & $\mathrm{O}(1)-(\mathrm{Si} A \mathrm{Al})-\mathrm{O}(3)$ & $112.1(3)$ \\
(Si,Al)-O(3) & $1.684(3)$ & $\mathrm{O}(2)-(\mathrm{Si} \mathrm{Al})-\mathrm{O}(3)$ & $106.8(3)$ \\
& & $\mathrm{O}(3)-(\mathrm{Si}, \mathrm{Al})-\mathrm{O}(3)$ & $110.5(5)$ \\
$\mathrm{Zn}(1)-O(3)$ & $2.215(14)$ & & \\
$\mathrm{Zn}(2)-\mathrm{O}(3)$ & $2.165(10)$ & $(\mathrm{Si}, \mathrm{Al})-\mathrm{O}(1)-(\mathrm{Si}, \mathrm{Al}) 154.6(6)$ \\
$\mathrm{Zn}(3)-\mathrm{O}(3)$ & $2.248(10)$ & $(\mathrm{Si}, \mathrm{Al})-\mathrm{O}(2)-(\mathrm{Si}, \mathrm{Al}) 151.8(5)$ \\
$\mathrm{K}(1)-\mathrm{O}(3)$ & $2.594(11)$ & $(\mathrm{Si}, \mathrm{Al})-\mathrm{O}(3)-(\mathrm{Si}, \mathrm{Al}) 138.4(6)$ \\
$\mathrm{K}(2)-\mathrm{O}(3)$ & $3.26(3)$ & & \\
$\mathrm{K}(3)-\mathrm{O}(2)$ & $2.78(5)$ & $\mathrm{O}(3)-\mathrm{Zn}(1)-\mathrm{O}(3)$ & $115.1(9)$ \\
$\mathrm{K}(4)-\mathrm{O}(1)$ & $2.92(6)$ & $\mathrm{O}(3)-\mathrm{Zn}(2)-\mathrm{O}(3)$ & $119.3(2)$ \\
& & $\mathrm{O}(3)-\mathrm{Zn}(3)-\mathrm{O}(3)$ & $112.4(3)$ \\
$\mathrm{Zn}(1)-\mathrm{I}(1)$ & $3.35(5)$ & $\mathrm{O}(3)-\mathrm{K}(1)-\mathrm{O}(3)$ & $92.2(4)$ \\
$\mathrm{K}(1)-\mathrm{I}(1)$ & $3.33(8)$ & $\mathrm{O}(3)-\mathrm{K}(2)-\mathrm{O}(3)$ & $69.9(7)$ \\
$\mathrm{Zn}(3)-\mathrm{I}(2)$ & $3.23(9)$ & & \\
$\mathrm{K}(2)-\mathrm{I}(2)$ & $3.09(9)$ & $\mathrm{I}(1)-\mathrm{Zn}(1)-\mathrm{I}(1)$ & $59.5(21)$ \\
$\mathrm{K}(4)-\mathrm{I}(2)$ & $3.39(5)$ & $\mathrm{O}(3)-\mathrm{Zn}(1)-\mathrm{I}(1)$ & $84.6(12) / 138.0(17)$ \\
$\mathrm{K}(1)-\mathrm{I}(3)$ & $3.243(18)$ & $\mathrm{Zn}(3)-\mathrm{I}(2)-\mathrm{K}(2)$ & $146(3)$ \\
$\mathrm{K}(3)-\mathrm{I}(3)$ & $3.23(6)$ & $\mathrm{Zn}(3)-\mathrm{I}(2)-\mathrm{K}(4)$ & $85.8(16)$ \\
& & $\mathrm{K}(2)-\mathrm{I}(2)-\mathrm{K}(4)$ & $93.3(14)$ \\
$\mathrm{Zn}(1) \cdots \mathrm{K}(2)$ & $2.945(6)$ & $\mathrm{K}(1)-\mathrm{I}(3)-\mathrm{K}(1)$ & $134.4(14)$ \\
$\mathrm{Zn}(1) \cdots \mathrm{I}(1)$ & $1.39(8)$ & $\mathrm{K}(1)-\mathrm{I}(3)-\mathrm{K}(3)$ & $103.0(7) / 120.8(10)$ \\
$\mathrm{I}(1) \cdots \mathrm{I}(1)$ & $3.32(13)$ & & \\
$\mathrm{I}(1) \cdots \mathrm{O}(3)$ & $2.87(5)$ & & \\
$\mathrm{I}(2) \cdots O(3)$ & $3.67(10)$ & & \\
$\mathrm{I}(3) \cdots O(1)$ & $3.02(4)$ & & \\
\hline
\end{tabular}

"The numbers in parentheses are the estimated standard deviations in the units of the least significant digit given for the corresponding parameters. and $\mathrm{Zn}(3)$ in the large cavities are 2.215(14). 2.165(10), and $2.248(10)$ A. respectively. away from three $O(3)$ oxygens. The approach distance from the $\mathrm{Zn}^{\hat{2}^{-}}$ions on the 3-fold axis to $O(3) . Z n(1)-O(3)=2.215(14) A . Z n(2)-O(3)=2.165(10)$ $A$, and $Z n(3)-O(3)=2.248(10) A$. are reasonable considering the distances of $\mathrm{Zn}^{2-}$ to the framework oxygen that were found in previous works $(1.99 \AA \text { to } 2.30 \AA)^{16.3}$ and the sum of ionic radii of $\mathrm{Zn}^{2-}$ and $\mathrm{O}^{2-}, \gamma_{\mathrm{Zn}^{2}}{ }^{--}(0.74 \AA)+\gamma_{0^{2-}}(1.32 \AA)$ $=2.06 \mathrm{~A}^{26}$ with their esds.

$\mathrm{K}^{-}$ions at $\mathrm{K}(\mathrm{l})$ and $\mathrm{K}(2)$ are $2.584(11) \AA$ and $3.26(3) \AA$. respectively, from three $O(3)$ oxygens of a 6-ring (see Table 4). The $\mathrm{K}(1)-\mathrm{O}(3)$ distance. $2.584(11) \mathrm{A}$. is similar to the sum of the ionic radii of $\mathrm{K}^{+}$and $\mathrm{O}^{-2} .1 .33 \AA+1.32 \AA=2.65$ $A^{26}$ but the $\mathrm{K}(2)-\mathrm{O}(3)$ distance. $3.26(3) \AA$. is much longer than the sum. Such somewhat longer approach distances from framework oxygens can be explained by all of $\mathrm{K}^{+}$ions at $\mathrm{K}(2)$ making clusters with $\mathrm{I}^{-}$ions or $\mathrm{H}_{2} \mathrm{O}$ molecules in the large cavities (vide infro). These longer distances of $\mathrm{K}^{+}$ions are also observed in dehỵdrated $\left|\mathrm{K}_{12}\right|\left[\mathrm{Si}_{12} \mathrm{Al}_{1_{2}} \mathrm{O}_{48}\right]$-LTA and hydrated $\left|\mathrm{K}_{12}\right|\left[\mathrm{Si}_{1} \mathrm{Al}_{12} \mathrm{O}_{48}\right]$-LTA ${ }^{21}$ The $\mathrm{K}^{-}$ions at $\mathrm{K}(\mathrm{l})$ and $\mathrm{K}(2)$ extend $1.44 \mathrm{~A}$ and $2.45 \mathrm{~A}$. respectively. into the large cavity from the (111) planes at $\mathrm{O}(3)$ (see Table 5), and make different angles with $\mathrm{O}(3) . \mathrm{O}(3)-\mathrm{K}(1)-\mathrm{O}(3)=92.2(4)^{\circ}$ and $\mathrm{O}(3)-\mathrm{K}(2)-\mathrm{O}(3)=69.9(7)^{\circ}$. Additionally. the $\mathrm{K}(1)-\mathrm{O}(3)$ distance $2.584(11) \mathrm{A}$. is very close to the calculated K-O distance. $2.65 \mathrm{~A} .{ }^{36}$ because two thirds of the $\mathrm{K}^{+}$ions at $\mathrm{K}(\mathrm{l})$ bond to $\mathrm{I}^{-}$ions at $\mathrm{I}(\mathrm{l})$ in the sodalite cavities and also bond to $\mathrm{I}^{-}$ions at $\mathrm{I}(3)$ in the large cavities with their reasonable

Table 5. (Si,Al)-O-(Si,Al) Angles (deg) at Framework Oxygens and Unit Cell Parameters for $\mathrm{K}^{-}$- and $\mathrm{Zn}^{2+}$-exchanged Zeolite A

\begin{tabular}{|c|c|c|c|c|}
\hline Zeolites & $O(1)$ & $O(2)$ & $O(3)$ & $a, \AA$ \\
\hline Dellydrated $\left|\mathrm{K}_{12}\right|\left[\mathrm{Si}_{12} \mathrm{Al}_{l_{2}} \mathrm{O}_{48}\right]-\mathbf{L T A}^{b}$ & $128.5(6)$ & $178.4(5)$ & $153.7(5)$ & $12.3(09(2)$ \\
\hline Hydrated $\left|\mathrm{K}_{12}\right|\left[\mathrm{Si}_{12} \mathrm{Al}_{12} \mathrm{O}_{48}\right]-\mathbf{L T A}^{b}$ & $145.2(9)$ & $159.3(6)$ & $1460.99)$ & $12.301(2)$ \\
\hline Evacuated $\left|\mathrm{Zn}_{6}\right|\left[\mathrm{Si}_{1_{2}} \mathrm{Al}_{1_{2}} \mathrm{O}_{48}\right]-\mathbf{L T A}^{c}$ & $176.3(5)$ & $144.9(6)$ & $130.5(4)$ & $12.049(1)$ \\
\hline Hydrated $\left|\mathrm{Zn}_{6}\right|\left[\mathrm{Si}_{12} \mathrm{Al}_{12} \mathrm{O}_{48}\right]-\mathbf{L T A}^{c}$ & $160.0(8)$ & $150.0(9)$ & $139.5(7)$ & $12.163(1)$ \\
\hline Evacuated $\left|\mathrm{K}_{2} \mathrm{Zn}_{1}\right|\left[\mathrm{Si}_{1_{2}} \mathrm{Al}_{l_{2}} \mathrm{O}_{48}\right]-\mathbf{L T A}^{\prime}$ & $156.1(10)$ & $149.4(7)$ & $136.7(6)$ & $12.075(2)$ \\
\hline$\left|\mathrm{K}_{6} \mathrm{Zn}_{3}(\mathrm{KI})_{3}\left(\mathrm{ZnI}_{2}\right)_{0} \leq\left(\mathrm{H}_{2} \mathrm{O}\right)_{k}\right|\left[\mathrm{Si}_{1} \mathrm{Al}_{1} \mathrm{Al}_{1} \mathrm{O}_{4,8}\right]-\mathbf{L T A}^{e}$ & $154.6(6)$ & $151.8(5)$ & $138.4(6)$ & $12.169(1)$ \\
\hline
\end{tabular}

"The numbers in parentheses are the estimated standard deviations in the units of the least significant digit given for the corresponding parameters. ${ }^{5}$ Reference 21 . 'Reference 16. 'Reference 20. ${ }^{\text {T This work: }}$

Table 6. Deviations of Atoms $(A)$ from the (111) Plane at $O(3)^{a}$

\begin{tabular}{|c|c|c|c|c|c|c|}
\hline & $\left|\mathrm{K}_{6} \mathrm{Zn}_{3}(\mathrm{KI})_{3}\left(\mathrm{ZnI}_{2}\right)_{0.5}\right|-\mathbf{L T} \mathbf{A}^{b}$ & $\begin{array}{c}\text { Evacuated } \\
\left|\mathrm{K}_{:} \mathrm{Zn}_{\mathrm{n}}\right|-\mathrm{LTA}^{c}\end{array}$ & $\begin{array}{l}\text { Dehydrated } \\
\left|2 \mathbf{n}_{k}\right|-\text { LTA }^{d}\end{array}$ & $\begin{array}{l}\text { Hydrated } \\
|2 \mathbf{n}|-\text { LTA }^{\prime \prime}\end{array}$ & $\begin{array}{l}\text { Dehydrated } \\
\left|\mathrm{K}_{|:|}\right|-\text {LTA }^{e}\end{array}$ & $\begin{array}{l}\text { Hydrated } \\
\left|\mathrm{K}_{12}\right|-\text { LTA }^{*}\end{array}$ \\
\hline $\operatorname{Zn}(1)$ & -0.50 & -0.59 & -0.64 & -3.86 & & \\
\hline $\operatorname{Zn}(2)$ & 0.18 & 0.20 & 0.16 & 0.66 & & \\
\hline $\operatorname{Zn}(3)$ & 0.63 & 0.91 & & & & \\
\hline $\mathrm{K}(1)$ & 1.44 & & & & 0.79 & 1.49 \\
\hline $\mathrm{K}(2)$ & 2.45 & & & & & \\
\hline $\mathrm{K}(3)$ & & & & & 3.45 & 5.26 \\
\hline $\mathrm{K}(4)$ & & & & & -1.35 & \\
\hline$K(5)$ & & & & & -0.19 & \\
\hline$I(1)$ & -1.89 & & & & & \\
\hline$O(4)$ & & -2.76 & & -1.93 & & 3.34 \\
\hline$O(5)$ & & 2.92 & & 2.63 & & -1.94 \\
\hline
\end{tabular}

"A positive deviation indicates that the ion lies in the large carity: A negative deviation indicates that the ion lies on the same side of the plane as the origin. i.e.. inside the sodalite unit. " This work. 'Reference 20 . 'Reference 16 . 'Reference 21. 


\section{distances and structure (vide infro)}

Per unit cell. two $\mathrm{K}^{-}$ions at $\mathrm{K}(3)$ are found on near 8-rings and two $\mathrm{K}^{+}$ions at $\mathrm{K}(4)$ are also found on deeply off the plane of the 8-rings in the large cavities. The $\mathrm{K}^{+}$ions at $\mathrm{K}(3)$ and $\mathrm{K}(4)$ are 2.78(5) $\AA$ and 2.92(6) $\AA$ from framework oxygen at $O(2)$ and $O(1)$. respectively. The approach distance is somewhat longer than the calculated one. $2.65 \mathrm{~A}$. but the longer distances of 8-ring cations from the framework oxygen are observed in many monopositive cationic forms of zeolite A. The two kinds of crystallographic positions and somewhat longer distances of 8-ring cations can be explained by existence of two kinds of $\mathrm{K}^{-}$-included clusters near 8-rings in the large cavities (ride infro).

Including all of the cationic ions that are found. the total charge of the unit cell is $+3.34((3.5 \times(+2))+(9.0 \times(+1))-$ $12=+16.0$ ). This is because occupancies of all of $\mathrm{Zn}^{2-}$ and $\mathrm{K}^{-}$ions per unit cell are 3.5 and 9, respectively, and the charge of framework per unit cell is -12 . Therefore. some additional negative ions are needed in the unit cell to make neutral charged unit cells. This is shown in Tables 2 and 3 .

$\mathbf{Z n I}_{2}$ Molecule in the Sodalite Unit. In the sodalite units. $0.5 \mathrm{Zn}^{\hat{2}^{-}}$ions and one $\mathrm{I}^{-}$ion per unit cell occupy nonequivalent 3-fold axes positions. indicating a $\mathrm{ZnI}_{2}$ molecule is formed in $50 \%$ of the sodalite units. The $0.5 \mathrm{Zn}^{3+}$ ions at $\mathrm{Zn}(1)$ lie opposite a 6 -ring in the sodalite unit and the one $\mathrm{I}^{-}$ ion at $\mathrm{I}(\mathrm{l})$ occupies a similar positions, recessed more deeply into the sodalite unit. It is impossible for both a $\mathrm{Zn}^{2-}$ and a $\mathrm{I}^{-}$ ion to approach the same 6-ring because their approach distance. 1.39(8) A would be too short.

Each $\mathrm{Zn}^{3+}$ ion at $\mathrm{Zn}(\mathrm{l})$ is $2.215(14) \AA$ from three $\mathrm{O}(3)$ oxygens of a 6-ring (see Table 4) and extend $0.50 \mathrm{~A}$ into the sodalite unit from the (111) planes at $O(3)$ (see Table 6). The $\mathrm{Zn}(1)-\mathrm{O}$ (3) distance. $2.215(14) \mathrm{A}$. is similar to those were found in previous works $(1.99 \AA \text { to } 2.30 \AA)^{16,30}$ and indicate the ion at $\mathrm{Zn}(1)$ are $\mathrm{Zn}^{3+}$ ions.

The occupancy of $\mathrm{I}^{-}$ion at $\mathrm{I}(\mathrm{l})$. 1.0. is equal to twice of that of $\mathrm{Zn}^{2-}$ ions at $\mathrm{Zn}(\mathrm{l}) .0 .5$. and extend $1.89 \AA$ into the sodalite unit from the (111) planes at $O(3)$ (see Table 6). They are thus far from the three nearest anionic framework oxygens. indicating that they are not cations. Furthermore. the bonding distance of $\mathrm{I}(1)$ to the nearest $\mathrm{Zn}^{\mathrm{n}^{-}}$ion at $\mathrm{Zn}(\mathrm{l})$. $3.35(5) \mathrm{A}$. is somewhat longer than the sum of ionic radii of $\mathrm{Zn}^{3-}$ and $\mathrm{I}^{-}, \gamma_{\mathrm{Zn}^{3}}{ }^{3+}(0.74 \AA)+\gamma_{1}^{-}(2.16 \AA)=2.90 \AA^{36}$ The $\mathrm{I}^{-}$ ions at $\mathrm{I}(1)$ lie on the other side of 6-rings that are occupied with $\mathrm{K}^{+}$ions at $\mathrm{K}(1)$ in the large cavities and can bond to $\mathrm{K}^{+}$ ions at $\mathrm{K}(1)$ opposite adjacent 6 -rings $(\mathrm{K}(\mathrm{l})-\mathrm{I}(\mathrm{l})=3.33(8)$ A). Considering the sum of ionic radii between $\mathrm{K}^{-}$and $\mathrm{I}^{-}$. $\gamma_{\mathrm{K}^{-}}(1.33 \AA)+\gamma^{-}(2.16 \AA)=3.49 \AA .{ }^{3}$ and its esd. the $\mathrm{K}(1)$ I( I) distances are reasonable.

Considering the occupancies of $\mathrm{Zn}^{2-}$ ions at $\mathrm{Zn}(1)$ and $\mathrm{I}^{-}$ ion at $\mathrm{I}(1), 0.5$ and 1.0 , respectively. (see Table 2 ) and the possible arrangements of $\mathrm{Zn}^{2-}$ and $\mathrm{I}^{-}$ions within the space of the sodalite unit, one $\mathrm{Znl}_{2}$ molecule in the $50 \%$ of the sodalite units is most likely (see Figures 1, 2. and 3). In this arrangement. one $\mathrm{Zn}^{3+}$ ion bonds to two $\mathrm{I}^{-}$ions (in addition to three framework oxy gens). and each $\mathrm{I}^{-}$ion bonds to one $\mathrm{Zn}^{3-}$ ion (in addition to one $\mathrm{K}^{+}$ion at $\mathrm{K}(\mathrm{l})$ ). The stereoview
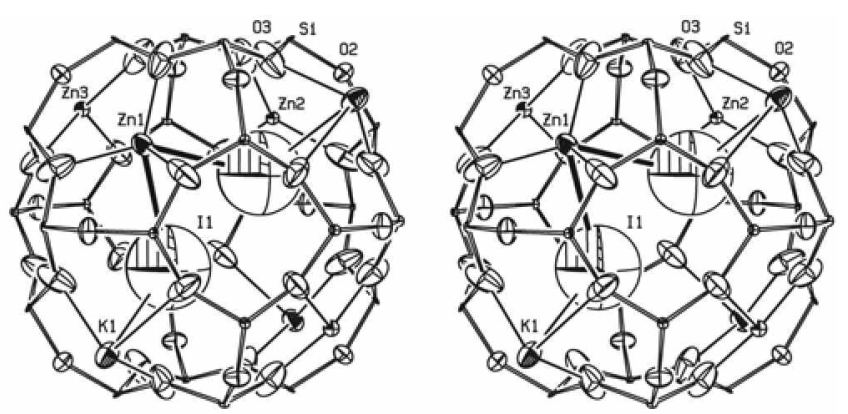

Figure 1. A stereoview of a sodalite cavity in $\left|\mathrm{K}_{\mathrm{i}} \mathrm{Zn} \mathrm{n}_{3}(\mathrm{KI})_{3}\left(\mathrm{ZnI}_{2}\right)_{1}\right|_{-}$ $\left[\mathrm{Si}_{2} \mathrm{Al}_{12} \mathrm{O}_{48}\right]$-LTA containing a $\mathrm{ZnI} \mathrm{I}_{2}$ molecule. $50 \%$ of the sodalite cavities contain a $\mathrm{Znl}_{2}$ molecule (heavy lines) as shown. One $\mathrm{Zn}^{2-}$ at $\mathrm{Zn}(1)$ coordinate to three $O(3)$ oxygens. The zeolite A tramework is drawn with bonds of medium thickness between oxygens and tetrahedrally coordinated (Si,Al) atoms. The coordinations of $\mathrm{K}^{+}$and $\mathrm{Zn}^{2+}$ ions to oxygens of zeolite framework are indicated by the thimnest lines. Ellipsoids of $20 \%$ probability are shown.

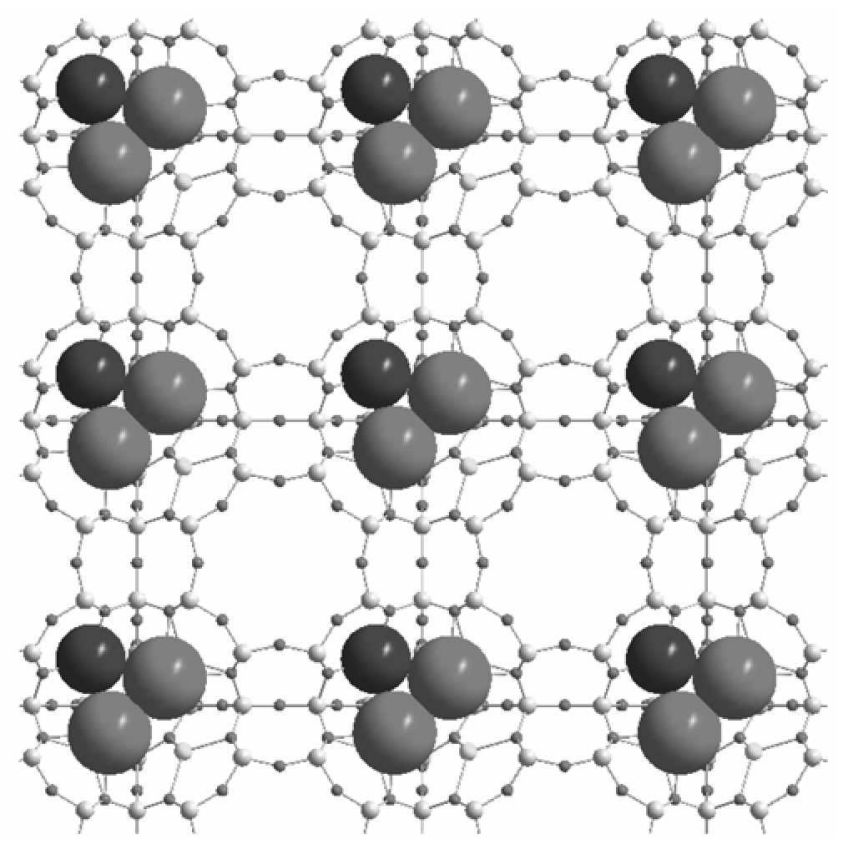

Figure 2. Two dimensional diagram of tramework, building units. cavities, and location $\mathrm{Zn}_{\mathrm{n}} \mathrm{L}_{2}$ molecules in sodalite cavities of several unit cells. for clarity, the framework atoms and cations have been simplitied. 'l'he long-range ordering and identical orientations of the nanoparticles shown here is reasonable, but it has not been established in this work.

of such a sodalite wit with a $\mathrm{ZnI}$, molecule is shown in Figure 1 .

The $\mathrm{ZnI}_{2}$ molecules in the sodalite cavities of this crystal are likely to be very stable because the absorbed and captured molecules within nano-sized spaces are highly resistant to high temperature and sudden changes in temperature and vacuum conditions. Additionally this synthesis method, dynamic ion-exchange with aqueous solutions at room temperature has been extensively used to make various other nanoclusters. $\mathrm{Ag}_{4} \mathrm{I}_{4} .{ }^{12} \mathrm{Ag}_{4} \mathrm{Br}_{4}{ }^{13}$ and $\mathrm{PbI}_{4}{ }^{1+}$ in the sodalite cavities because it is more productive and efficient compared to other methods such as thermal diffusion with 

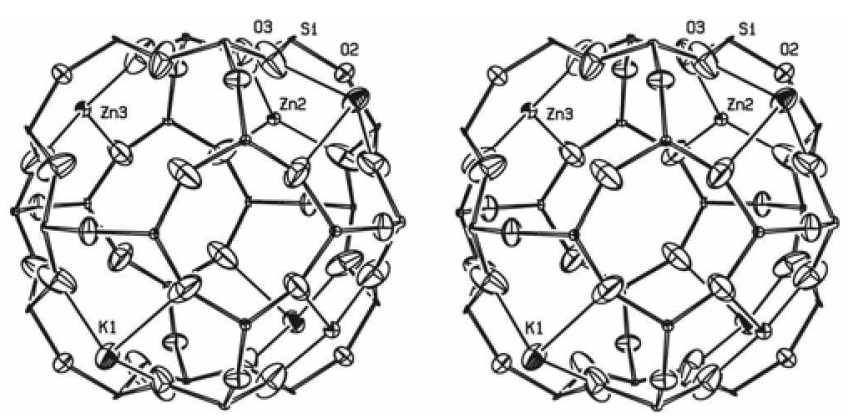

Figure 3. A stereoview of a sodalite cavity in $\left|\mathrm{K}_{1} \mathrm{Zn}_{3}(\mathrm{KJ}){ }_{3}\left(\mathrm{ZnI}_{2}\right)_{1} ;\right|-$ $\left[\mathrm{S}_{1,2} \mathrm{Al}_{1}, \mathrm{O}_{48}\right]$-LTA without contanning anv $\mathrm{ZnI}_{2}$ molecule. See the caption to Figure I for other detarls.
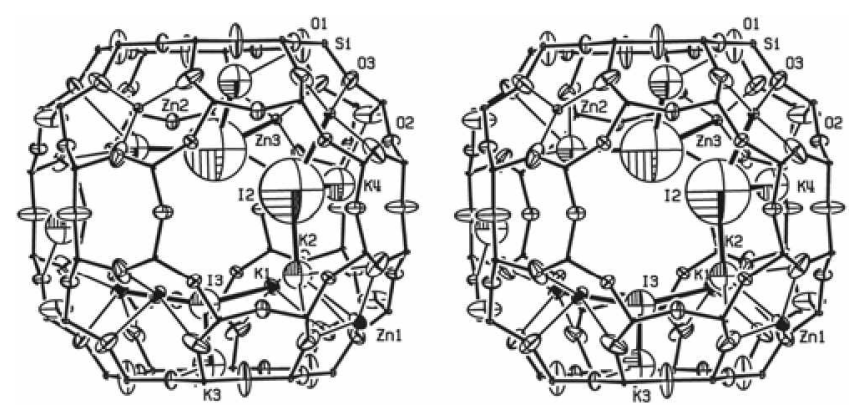

Figure 4. Stereoview of the large cavity of $\mid \mathrm{K}_{0} \mathrm{Zn}_{3}\left(\mathrm{KI}_{3}\left(\mathrm{ZnI}_{2}\right)_{0} \mathrm{~s} \mid-\right.$ $\left[\mathrm{S}_{1,2} \mathrm{Al}_{1} \mathrm{O}_{48}\right]$-LTA with $\mathrm{Zn}^{2+}$ at $\mathrm{Zn}(1)$. lwo $\mathrm{K}_{2} \mathrm{ZnI}^{3+}$ and a $\mathrm{K}_{3} \mathrm{I}^{2+}$ ionic clusters are shown in this figure. Heavy lines indicate $\mathrm{K}^{+}-\mathrm{I}^{-}$ and $\mathrm{Znn}^{{ }^{-}-\mathrm{I}^{-}}$bonds. See the caption to Figure 1 for other details.

\section{vapor.}

Zn-K-I Clusters in the Large Cavities. Three $\mathrm{I}^{-}$ions per unit cell are found opposite 4-rings in the large cavity: two at $\mathrm{I}(2)$ and one at I(3) per unit cell are opposite 4-ring in the large cavities. respectively. but the $\mathrm{I}^{-}$ions at $\mathrm{I}(2)$ and $\mathrm{I}(3)$ are found at two different positions (see Table 2). Therefore. two kinds of clusters with an $\mathrm{I}^{-}$ion at $\mathrm{I}(2)$ or $\mathrm{I}(3)$ are predicted: two clusters with an $\mathrm{I}^{-}$ion at $\mathrm{I}(2)$ and another with an I' ion at I(3)

Two $\mathrm{K}_{2} \mathrm{ZnI}^{3+}$ cluster per unit cell are found in the large cavities and each of those includes an $\mathrm{I}^{-}$ion at I(2). Each $\mathrm{K}_{2} \mathrm{ZnI}^{3+}$ cluster consists of two $\mathrm{K}^{-}$ions (one at $\mathrm{K}(2)$ and one at $\mathrm{K}(4))$, a $\mathrm{Zn}^{-+}$ion at $\mathrm{Zn}(3)$, and an $\mathrm{I}^{-}$ion at $\mathrm{I}(2)$ and has a trigonal plane form with its center at I(2) (see Figures 4 and 5). The approach distances of $\mathrm{K}(2)-\mathrm{I}(2) . \mathrm{K}(4)-\mathrm{I}(2)$, and $\mathrm{Zn}(3)-\mathrm{I}(2)$ are 3.09(9). 3.39(5), and 3.23(9) A respectively. The distances are reasonable with esds as compared with the calculated distance of 3.49 and $2.90 \mathrm{~A}$ for $\mathrm{Zn}-\mathrm{I}$ and K-I. respectively. The angles are also reasonable with a possible geometry of the moiety. too $\left(\mathrm{K}(2)-\mathrm{I}(2)-\mathrm{Zn}(3)=146(3)^{\circ}\right.$. $\mathrm{K}(4)-\mathrm{I}(2)-\mathrm{Zn}(3)=85.8(16)^{\circ}$, and $\left.\mathrm{K}(2)-\mathrm{I}(2)-\mathrm{K}(4)=93.3(14)^{\circ}\right)$. Additionally, the somewhat long distance of $\mathrm{K}(2)-\mathrm{O}(3)$, $3.26(3) \AA$ (vide stipra). can be explained by each of $\mathrm{K}^{-}$ions at $\mathrm{K}(2)$ making ionic bonds with an $\mathrm{I}^{-}$ion at $\mathrm{I}(2)$ in a $\mathrm{K}=\mathrm{ZnI}^{\mathrm{j}+}$ cluster.

The other iodide ion per unit cell is found at l(3), opposite a 4-ring in the large cavity. It bonds to three $\mathrm{K}^{+}$ions (two at $\mathrm{K}(\mathrm{l})$ and one at $\mathrm{K}(3)$ ) in a trigonal plane numer to give a
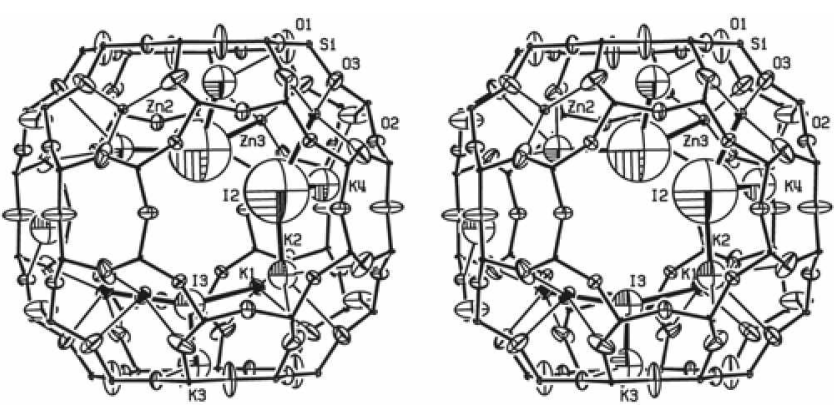

Figure 5. Stereoview of the large cavity of $\left|\mathrm{K}_{4} \mathrm{Zn}_{3}(\mathrm{KI})_{3}\left(\mathrm{ZnI}_{2}\right)_{1}\right|-$ $\left[\mathrm{Si}_{12} \mathrm{Al}_{12} \mathrm{O}_{48}\right]$-LTA without $\mathrm{Zn1^{2- }}$ at $\mathrm{Zn}(1)$. See the caption to Figures $\mathrm{I}$ and 3 for other details.

$\mathrm{K}_{3} \mathrm{I}^{2-}$ cluster (see Figures 4 and 5 ). The bonding distances of $\mathrm{K}(1)-\mathrm{I}(3)$ and $\mathrm{K}(3)-\mathrm{I}(3)$ are $3.243(18)$ and $3.23(6) \mathrm{A}$ respectively. These are close to the sum of K-I ionic radii, $3.49 \mathrm{~A}^{36}$ considering their esds. The angle of $\mathrm{K}(\mathrm{l})-\mathrm{l}(3)-\mathrm{K}(\mathrm{l})$ is $134.4(14)^{\circ}$ and those of $\mathrm{K}(1)-\mathrm{I}(3)-\mathrm{K}(3)$ are $103.0(7)^{\circ}$ and $120.8(10)^{\circ}$. Furthermore. the sum of these angles of the $\mathrm{K}_{3} \mathrm{I}^{2+}$ cluster is near $360^{\circ}, 134.4^{\circ}+103.0^{\circ}+120.8^{\circ}=358.2^{\circ}$, and indicate that each the $\mathrm{K}_{3} \mathrm{I}^{2+}$ cluster has a trigonal plane form. Each of these. three $\mathrm{K}^{-}$ions lie on an edge of the trigonal plane and the $\mathrm{I}^{\circ}$ ion is in the center of the plane.

\section{Summary}

$\mathrm{ZnI}_{2}$ molecules are synthesized into the molecular-dimensioned cavities of $\mid \mathrm{K}_{6}\left(\mathrm{Zn}_{3}(\mathrm{KI})_{3}\left(\mathrm{ZnI}_{2}\right)_{(15} \mid\left[\mathrm{Si}_{1_{2}} \mathrm{Al}_{1_{2}} \mathrm{O}_{48}\right]-\mathrm{LTA}\right.$ thorough the dynamic ion-exchange of $\left|\mathrm{Zn}_{6}\right|\left[\mathrm{Si}_{2} \mathrm{Al}_{12} \mathrm{O}_{48}\right]-$ LTA and $\mathrm{KI}$ in $\mathrm{CH}_{3} \mathrm{OH}$ solution at $294 \mathrm{~K}$. The crystal structure of the product $\left(\left|\mathrm{K}_{6} \mathrm{Zn}_{3}(\mathrm{KJ})_{3}\left(\mathrm{ZnI}_{2}\right)_{05}\right|\left[\mathrm{Si}_{12} \mathrm{Al}_{12} \mathrm{O}_{48}\right]-\right.$ LTA. $a=12.1690(10) \mathrm{A}$ ) was determined at $294 \mathrm{~K}$ by single-crystal X-ray diffraction in the space group $P m \overline{3}$ in with the final error index $R_{1}=0.078$ for 431 reflections which $F_{0}>4 \sigma\left(F_{0}\right)$. Half a $\mathrm{Zn}^{\hat{2}^{+}}$ion and one $\mathrm{I}^{-}$ion per unit cell are found in the sodalite cavities. indicating the fonmation of a $\mathrm{ZnI}_{2}$ molecule per unit cell in $50 \%$ of the sodalite cavities. Additionally. three $\mathrm{I}^{-}$ions per unit cell are also found opposite a 4-ring in the large cavity and form two $\mathrm{K}_{2} \mathrm{ZnI}^{3+}$ and $\mathrm{K}_{3} \mathrm{I}^{\hat{2}^{-}}$ionic clusters with $\mathrm{K}^{-}$and $\mathrm{Zn}^{2-}$ ions. The $\mathrm{ZnI}_{2}$ molecules in the sodalite cavities are probably highly resistant to heating and dehydration because they are stabilized by interactions with the framework atoms. The $\mathrm{ZnI}_{2}$ molecules are effectively synthesized in the sodalite cavities by dynamic ion-exchange method.

Acknowledgement. We gratefully acknowledge the support of the beamline 4A MXW of Pohang Light Source. Korea, for the diffraction and computing facilities. The research was supported by grants (3-6-2) from Sustainable Water Resources Research Center of $21^{\text {st }}$ Century Frontier Research Program.

Supporting Information: Observed and calculated structure factors for $\left|\mathrm{K}_{6} \mathrm{Zn}_{3}(\mathrm{KJ})_{3}\left(\mathrm{ZnI}_{2}\right)_{i_{3}}\right|\left[\mathrm{Si}_{12} \mathrm{Al}_{1_{2}} \mathrm{O}_{48}\right]$-LTA.

\section{References}


1. Naccache. C.: Taarit. Y. B. Zeolite: Science and Technologr. Martinus Nijhoft Publishers: The Hague. The Netherlands. 1984: pp 373-396.

2. Kim. H. S.: Kim. J. J.: Kwon. H. N.: Chung. M. J.: Lee. B. G.: Jang. H. G. J. Catal. 2002. 205, 226.

3. Rhodes, C. N.: Brown. D. R. J. Chem. Soc. Faraday Trans. 1993. $89,1387$.

4. Fraile. J. M.: Garcia. J. I.: Massam. J.: Mayoral. J. A.: Pires. E. J. Holecular Catal A Chentical 1997. 123.43.

5. Garcia. J. I: Mayoral. J. A.: Pires. E.: Brown. D. R.: Massam. Catal. Lett 1996.37,261

6. Kodomari, M.: Nagaoka. T:: Furusawa, Y. Tetrahedron Lett. 2001, 42,3105

7. Guisnet. M.: Perot. G. Zeolite: Science and Technologv: Martinus Nijhoff Publishers: The Hague. The Netherlands. 1984: pp 397420 .

8. Derouane. E. G. Zeolite: Science and Techlologv Martinus Nijhoff Publishers: The Hague. The Netherlands, 1984: pp 347371

9. Yasuda. M.: Tsuji. S.: Shigevoshi. Y: Bada. A. J. Amt Chent. Soc. 2002. 124. 7440

10. Tyagi. P.: Vedeshwar. A. G. Phnsical Review B 2001. 64. 245406

11. Tragi. P.: Vedeshwar A. G. Phis. Stat. Sol ta) 2002. 191.633.

12. Heo. N. H; Kim, H. S.; Lim. W. T; Seff. K. J. Phys. Chem. $B$ 2004, 108,3168.
13. Lim. W. T: Choi, S. Y.: Kim, B. J.; Kim, C. M.: Lee. I. S.: Kim. S. H.: Heo. N. H. Bull. Korean Chent. Soc. 2005. 26. 1090.

14. Kim. S. H.: Lim. W. T.: Kim. G. H.: Lee. H. S.: Heo. N. H. Bull Korean Chem. Soc. 2006. 27.679.

15. Charnell, J. F. J. Constal Growth 1971.8.291.

16. MeCusker. L. B.: Seff. K. J. Phns. Chem 1981, 85,405

17. Sheldrick. G. M. SHEL1Z97. Program for the Refinement of Crnstal Shrtures: University of Göttingen: Germany. 1997.

18. Cruz. W. V: Leung. P. C. W: Seff. K. J. Am. Chen. Sox. 1978. 100.6997

19. Mellum. M. D.: Seff, K. J. Phus. Chem. 1984, 88. 3560.

20. Raghavan. N. V; Seff. K. J. Plys. Chem. 1976. $80,2133$.

21. Leung. P. C. W.: Kunz. K. B.; Seff, K. d. Phys. Chem. 1975. 79 2157.

22. Doyle. P. A.: Tumer. P. S. deta Crnstallogr. Sect. A 1968. 24. 390 .

23. Intenational Tables for Mray Constallographn Ibers, J. A. Hamilton. W. C.. Eds.: Kynoch Press: Bimningham. England. 1974: Vol. IV. pp 71-98

24. Cromer. D. T. Acta Chstallogr. 1965. 18. 17.

25. International Tables for Mrat Chstallographn. Ibers. I. A. Hamilton. W. C.. Eds.: Kynoch Press: Birmingham. England. 1974: Vol. IV. pp 148-150.

26. Handbook of Chemistry and Physics, $6 f^{\text {th }}$ ed.; Chemical Rubber Co.: Cleveland. OH. 1983: p F-170. 